\title{
The use and arrangement of space at Meteora (1960 to present)
}

\subsection{Overview}

The changing wider circumstances of the operation of the site over time, namely the growth of the tourism and heritage industries, had implications on the use and arrangement of space. The evolution of the spatial arrangement in the recent history of Meteora may be summarised as follows:

\section{Phase A: the 1960s}

In this phase, the site operated primarily as a monastic one. This was clearly reflected in the use of space: The external and internal space of the monasteries was used primarily by the monastic communities and also the local community, who participated in the ritual life of the site as the congregation of the monasteries.

The concerns of the monastic communities as they were re-established in their monasteries were, in order of importance: the worship of God; their permanent residence in their monasteries; and the care for their predecessors. These concerns were manifested in the space of the monasteries as follows (Tetsios 2003, 345-347; pers. comm. Maximi).

- The katholicon. Reviving the function of the katholicon guaranteed the continuity of the conduct of the Holy Liturgy in the monastery.

- The cells, which covered a monastic community's basic need for accommodation. The permanent residence of a monastic community in the monastery was inextricably linked to the conduct of the Holy Liturgy. As soon as the local community (i.e. the congregation of the monastery) saw a monastic community having settled in a site, it offered its support in various ways, for example by providing food or construction materials (pers. comm. Maximi).

- The refectory, which provided the monastic community's food. The refectory is the second most important building in a monastery after the katholicon, closely linked to it in terms of symbolism and use (see above). Once a monastic community had its own 
refectory, it became independent, in the sense that it could survive on its own, without the aforementioned support of the local community (pers. comm. Maximi).

- An inside yard to connect the katholicon, the refectory and the cells. The yard is the quintessential element for the life of the monastic community and is also inextricably linked to the katholicon serving as its reception hall (see above).

- A storeroom for the protection of the past 'treasures' of the monastic community that are no longer in daily use [skeuofilakeio] (Tetsios 2003, 346-347; Tzimas 2000, 405 and 399; pers. comm. Ioasaph; pers. comm. Nikodimi). These 'treasures' are considered holy items and are also signs of the monastic community's temporal continuity (see above).

Therefore, in the first phase of the recent history of the site, the monastic communities focused mainly on the central part of their monasteries, i.e. that consisting of the katholicon, the refectory, the yard and the cells.

\section{Phase B: the 1970s and the early 1980s}

In this phase, the site remained primarily a monastic one, used mainly by the monastic communities and the congregation of the monasteries, which increased in size. The site also started developing as a tourist attraction (see above). As a consequence, the external and internal space of the monasteries, though still used mainly by the monastic communities and the congregation, started to be divided, in terms of use, between the monastic community and the congregation on the one hand and the visitors on the other.

The needs of the congregation were, in order of importance: to participate in the worship; to communicate with the members of the monastic community; and also have a meal with them. The monastic communities responded to the needs of the congregation in the following ways (pers. comm. Tetsios; pers. comm. Maximi).

- A larger church, which accommodated the congregation's need to participate in the worship.

- A larger reception hall [archontariki], which accommodated the congregation's need to communicate with the monastic community after the holy services, especially on Sundays and major feasts.

- A larger refectory, as a response to the congregation's need to have a meal with the monastic community after the holy services.

- A larger yard to connect the church, the reception hall and the refectory.

Therefore, in order to satisfy the needs of the congregation, the monastic communities made alterations to the central part of the monasteries, that consisting of the katholicon, the refectory and the yard (see phase A).

\section{Phase C: from the mid-1980s, especially the mid-1990s, to present}

This is the period of mass tourism. In this phase, the site remained a monastic one but at the same time has clearly developed into a major tourist attraction. This increasing emphasis on the tourist use of the site was clearly reflected in the use of space. The external space of the monasteries was used by the visitors, whilst the monastic communities were restricted to their monasteries. The internal space of the monasteries was divided, in terms of use, between the monastic communities on the one hand and the visitors on the other (see above).

The monastic communities attempted to satisfy the needs of the visitors in the following ways (Tzimas 2000, 396-406). 
- A variety of museums/exhibition halls with items from the past life of the site (Tzimas 2000; Tetsios 2003, 346-347; Nikodimi 2001, 276-284). These museums should be differentiated from the storerooms of the 1960s-early 1970s (see phase A): the storerooms of the 1960s-early 1970s were mainly the expression of the monastic communities' need to protect the monastic 'treasures' (as an obligation of theirs towards the Tradition and their predecessors), while the museums under discussion were mainly the expression of the monastic communities' desire to exhibit a whole variety of items that they considered relevant to the visitors. Thus, refectories, hospitals, and houses for the elderly and other secondary buildings, no longer in use, were transformed into such museums.

- Space that allowed the visitors to move around the buildings of monasteries, and also admire the surrounding landscape. This space included: staircases and bridges for the easier access from the road to the monasteries, entrances and structures for the selling of tickets, larger inside yards, separating doors with signs preventing the visitors from entering the private areas of the monasteries, and signs asking the visitors to 'respect the holiness of the place'.

- Shops selling items about the site or monasteries in general and even some souvenirs from Greece in general.

- Structures that covered basic needs of the visitors, such as toilet facilities, drinking water facilities and telephone boxes.

Therefore, in order to satisfy needs of the visitors, the monastic communities changed mostly secondary and peripheral areas and buildings of the monasteries (and not the central part of the monasteries, as in phases $\mathrm{A}$ and $\mathrm{B}$ ).

\subsection{Examples}

The evolution of the spatial arrangement of the Meteora monasteries during the recent history can be examined in the following examples:

\section{The St Stephen monastery}

The St Stephen monastery has, relatively speaking for the standards of the site, a large available rock surface and is structured on a horizontal axis (Tzimas 2000, 398-401; Tetsios 2003, 343-347). The evolution of space may be seen in terms of the following phases:

Phase A: On reoccupying the monastery after the World War II and the Civil War, the monastic community transformed the refectory and the kitchen into halls for the exhibition of the monastic 'treasures', and constructed a new, much smaller, refectory and kitchen on the part of the monastery to the left of the entrance, together with the cells (figure 35). Thus, in this period, the life of the monastic community was mainly centred on the part of the monastery to the left of the entrance.

Phase B: The monastic community moved the refectory, the kitchen and the reception hall, and also constructed administrative offices and a library, to the part of the monastery to the right of the entrance (figure 36). This evolution of the spatial arrangement was the result of the monastic community's attempt to be closer to the congregation. Thus, at that time the life of the monastic community and of the congregation was mainly centred on the part of the monastery around the yard and the katholicon.

Phase C: The monastic community moved the refectory, the kitchen, the administrative offices, the library and the cells to a part even further to the right of the entrance. The monastic community also constructed a cemetery church on the very left corner (from the entrance) of the monastery (figure 37). It should be stressed at this point that the monastery has two katholica, an 


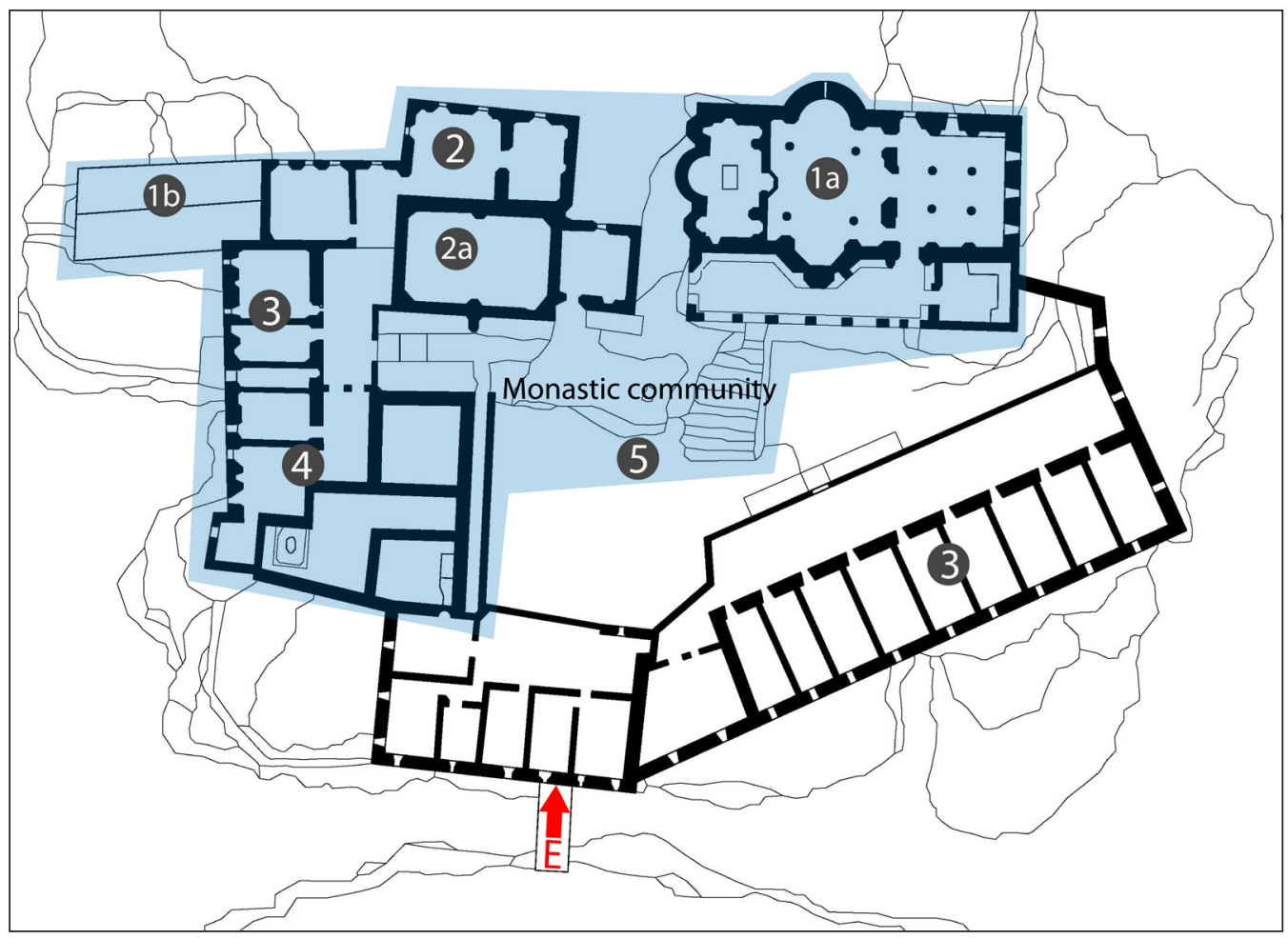

Figure 35: The St Stephen monastery: evolution of use of space, Phase A (see Papaioannou 1977, 30, with author's additions): The buildings of the St Stephen monastery, as shown in this figure, are: 1a: The later katholicon, dedicated to St Charalambos; 1b: The older katholicon, dedicated to St Stephen; 2: The original refectory, transformed into a museum for the 'treasures' of the monastery; 2a: The original kitchen, transformed into a museum for the 'treasures' of the monastery; 3: Cells; 4: Secondary buildings; 5: Yard; E: Entrance.

earlier one dedicated to St Stephen on the left corner of the monastery and a later one dedicated to St Charalambos in the centre of the monastery. Initially the visitors had access only to the katholicon in the centre of the monastery, while the monastic community used the other one. Over the course of time, however, the monastic community gave into the increasing pressure of the visitors to have access to the other katholicon as well (pers. comm. St Stephen Monastery). This change of the spatial arrangement related to the monastic community's attempt to stay as far as possible from the visitors. Thus, it is mainly the visitors who use the part of the monastery around the yard, while the monastic community uses the peripheral buildings of the monastery: mainly the part of the monastery to the right of the entrance and also the part of the monastery to the left of the entrance.

\section{The Roussanou monastery}

The Roussanou monastery has the most limited available surface at Meteora and is structured on a vertical axis (Tzimas 2000, 401-403; Tetsios 2003, 343-347).

Phase A: On return to the monastery after the wars, the monastic community retained the existing arrangement of space. The monastic cells, the refectory and the kitchen remained to the right of the entrance of the monastery, on the upper, main storey of the monastery (i.e. the storey of the katholicon). This space was shared by the monastic community and the large congregation. 


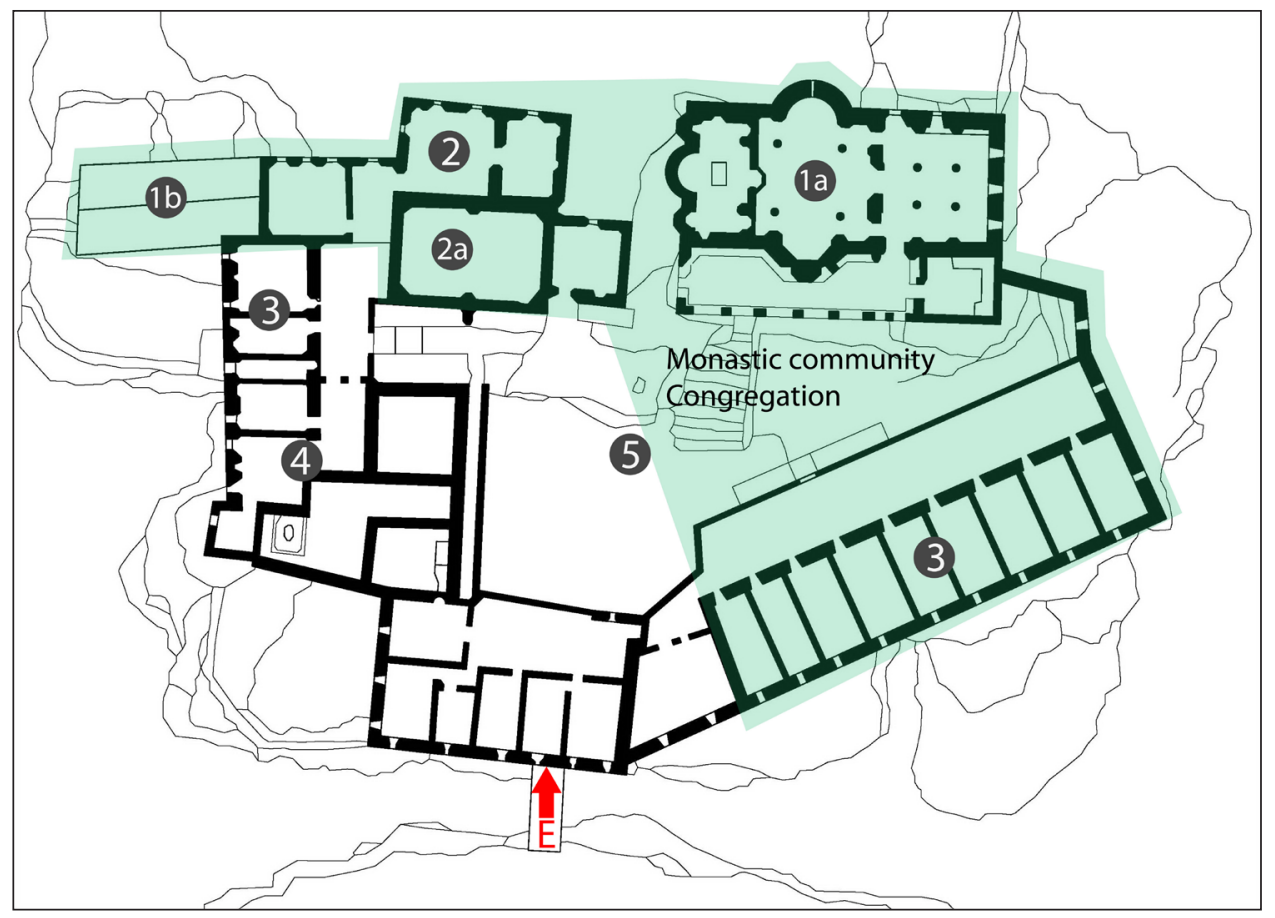

Figure 36: The St Stephen monastery: evolution of use of space, Phase B (see Papaioannou 1977, 30, with author's additions). Concerning the buildings: see figure 35 .

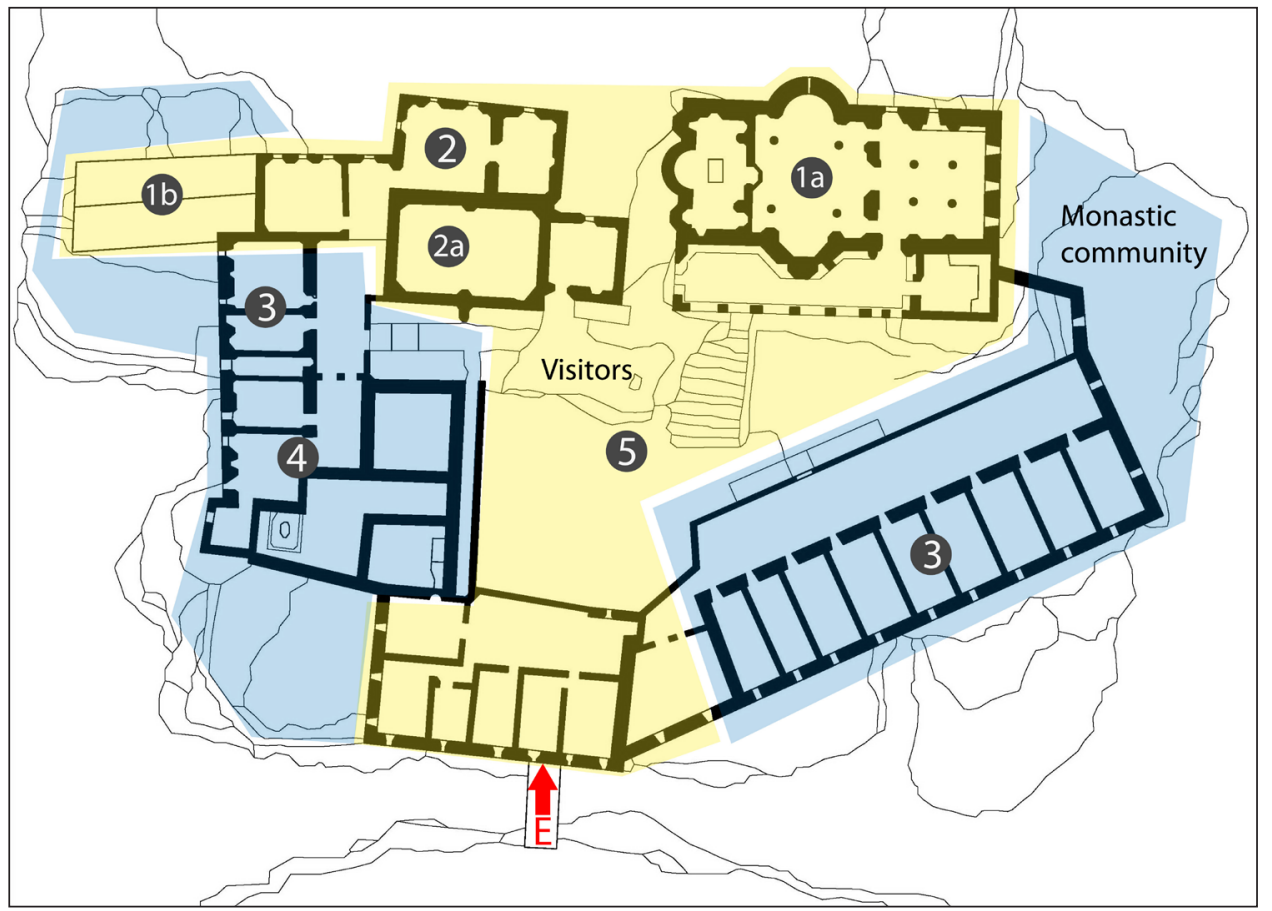

Figure 37: The St Stephen monastery: evolution of use of space, Phase C (see Papaioannou 1977, 30, with author's additions): Concerning the buildings: see figure 35. 
Phase B: The monastic community moved the cells, the refectory, the kitchen and a small library, and also constructed an enclosed balcony (see above), in the lower storey of the monastery (i.e. below the storey of the katholicon). Thus, the upper, main storey of the monastery was used by the visitors, while the lower storey was used by the monastic community. This evolution of the spatial arrangement demonstrated the need for the monastic community to stay as far as possible from the visitors, even in such severely limited space.

Phase C: Recently the monastic community erected a separate five storey building next to the Roussanou rock for their exclusive use (see above). The visitors have access to the original monastery, while the monastic community occupies the new building outside the original monastery (see above, figure 32). The evolution of the spatial arrangement showed the monastic community's attempt to stay even further from the increased pressure of mass tourism.

\section{The Holy Trinity monastery}

The Holy Trinity monastery has, relatively speaking for the standards of the site, an average available rock surface at Meteora and is structured on a horizontal axis (Tetsios 2003, 376-377; Tzimas 2000, 403-404).

Phase A: On reoccupying the monastery after the wars, the monastic community constructed cells and various secondary monastic buildings in the lower storey of the monastery (figure 38). At that time, the life of the monastic community was mainly centred on the katholicon.

Phase B: The monastic community transformed the original refectory opposite the katholicon into a larger church, so that it would accommodate the increased in size congregation, and the cells into a reception hall, and also formed an inside corridor (used as a yard) connecting the katholicon, the new church, the reception hall and the refectory (pers. comm. Lazaros Deriziotis; pers. comm. Tetsios) (figure 39). It is worth noting that the reception hall of the Holy Trinity monastery was altered twice in order to adjust to the continually increasing size of the congregation over the course of time (pers. comm. Tetsios). At that time, the space of the monastery was unified, and shared by the monastic community and the congregation.

Phase C: Today the visitors have access to the entire lower storey of the monastery, while the monastic community is mostly restricted on the upper storey of the monastery, consisting of cells and a small library (figure 40).

As these examples of monasteries show, the use of the internal space of the monasteries over time, with a specific emphasis on the katholicon (i.e. the core of the monastery), may be summarised as follows. In Phase A, the monastic community was mostly using the space around the original katholicon. In Phase B, the monastic community and the large congregation mainly used the space around either the original katholicon (as in the St Stephen and the Roussanou monasteries) or a new, larger church (as in the Holy Trinity monastery). In Phase C, the visitors have access to the original katholicon, while the monastic community uses another church (as in the Roussanou and the St Stephen monasteries).

\section{Conclusion}

The analysis of the evolution of the use of space in the recent history of the site leads to the following conclusions.

On reoccupying the site (phase A), the monastic communities maintained, in most of the cases, the existing arrangement of space of their monasteries. Later, however, in order to respond to the needs of the large congregation and especially the needs of the visitors, they changed the existing arrangement of space: they changed the central part of their monasteries (in phase B) and the periphery of their monasteries (in phase $\mathrm{C}$ ). 


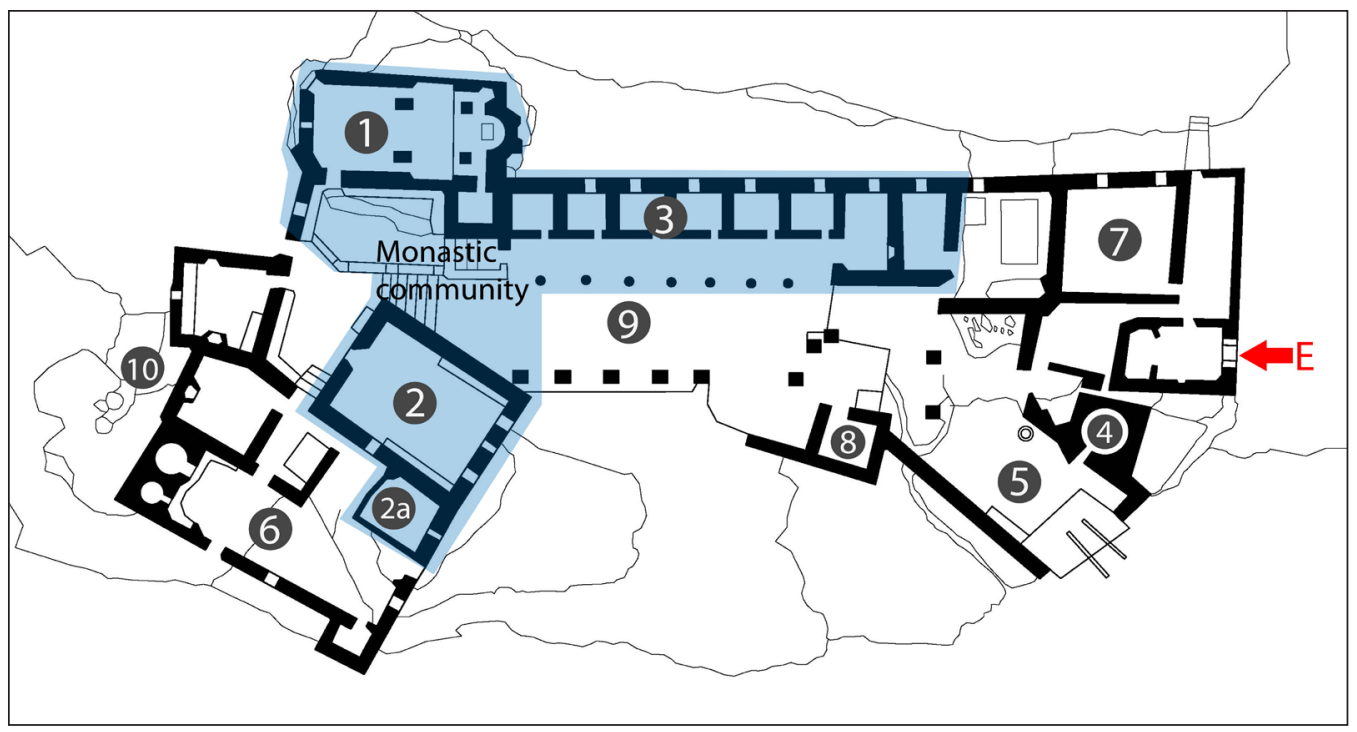

Figure 38: The Holy Trinity monastery: evolution of use of space, Phase A (see Papaioannou 1977,30 , with author's additions; for an external view of the monastery see above, figure 1). The buildings of the Holy Trinity monastery, as shown in this figure, are: 1: Katholicon; 2: Original refectory, transformed into a church (larger than the katholicon); 2a: Original kitchen, today part of the new church (number 2); 3: Original cells, partly demolished and partly transformed into secondary buildings, mainly storerooms. 4: Chapel of St John; 5: The vrizoni tower (i.e. the original way of access to the monastery); 6: Secondary buildings; 7: Original reception hall, transformed into a large refectory; 8: Original secondary building, transformed into a large reception hall [archontariki] and a small kitchen; 9: The inside corridor, used as an inside yard; $\mathrm{E}$ : The current entrance, which has replaced the tradition means of access to the monastery / the vrizoni (number 5).

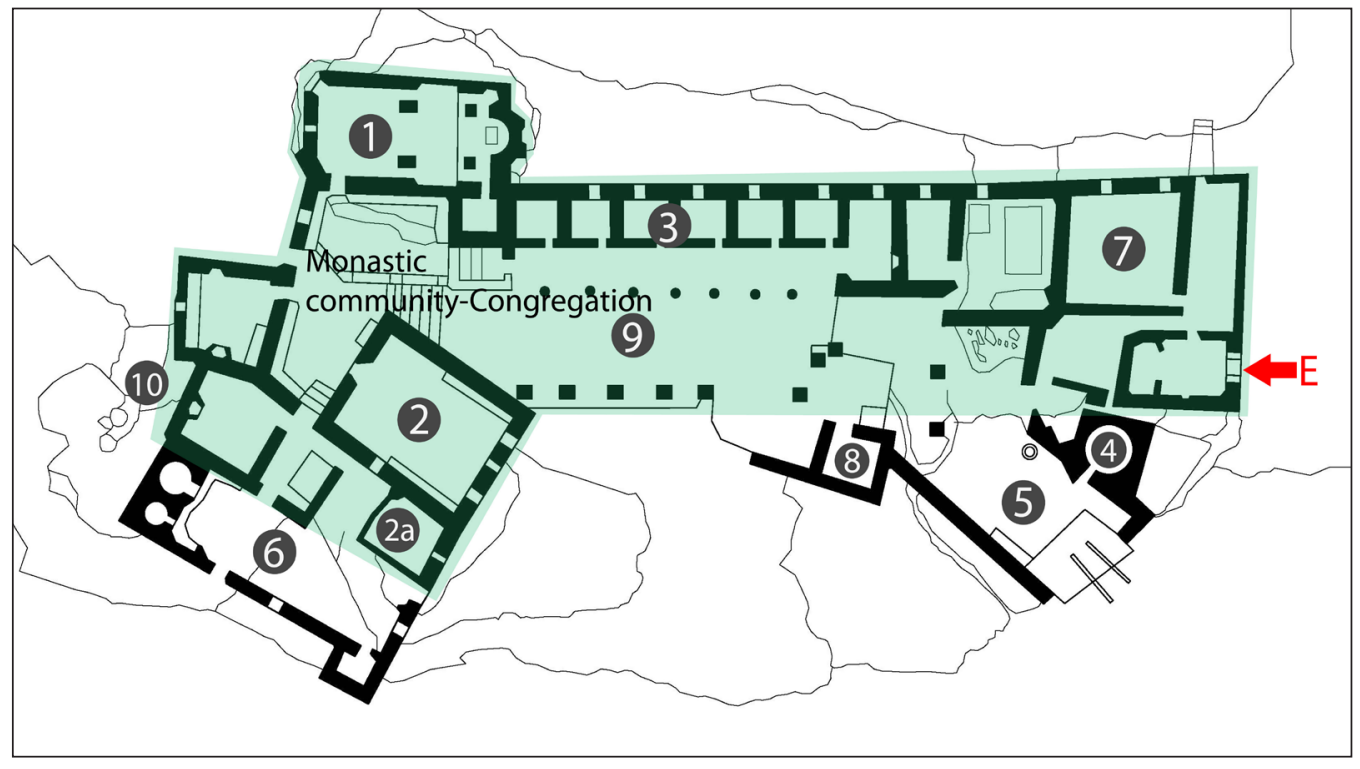

Figure 39: The Holy Trinity monastery: evolution of use of space, Phase B (see Papaioannou 1977, 30, with author's additions) Concerning the buildings: see figure 38 . 


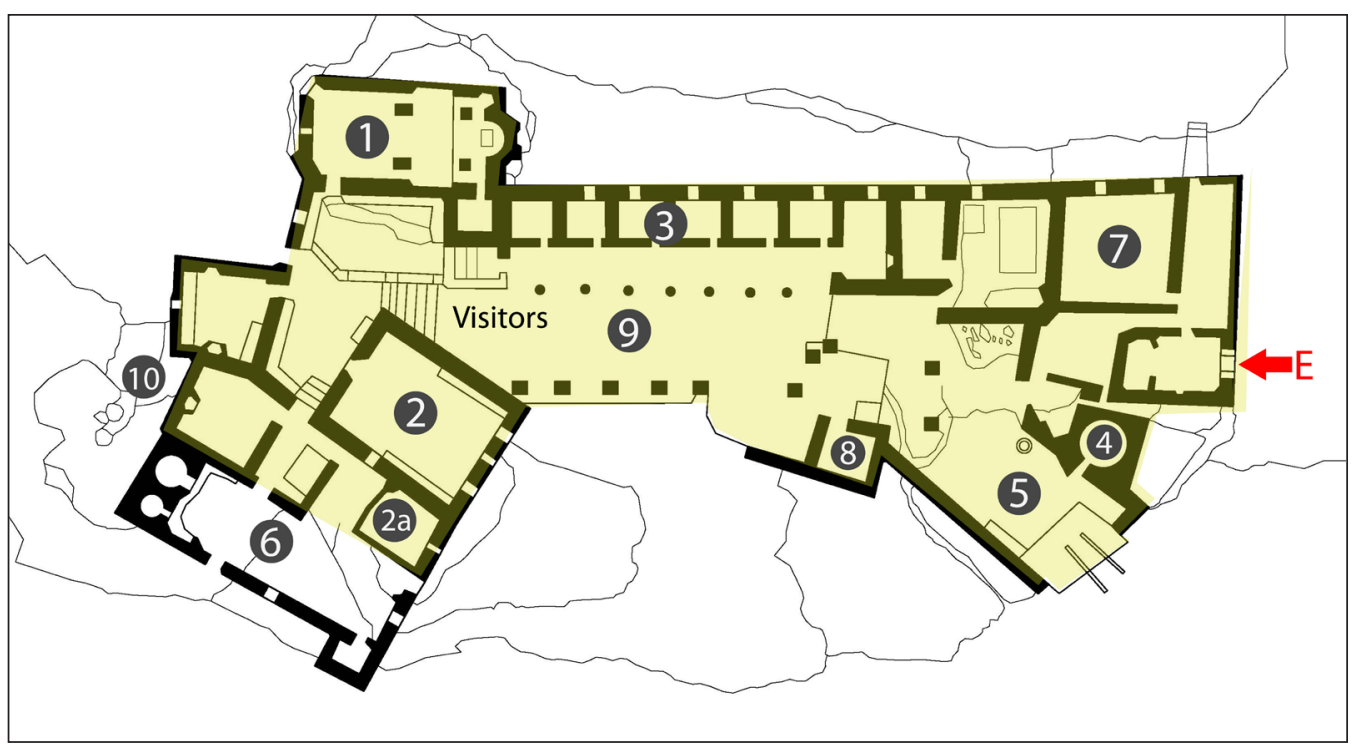

Figure 40: The Holy Trinity monastery: evolution of use of space, Phase C (see Papaioannou 1977, 30, with author's additions) Concerning the buildings: see figure 38 .

In every new arrangement of space, the monastic communities did not take into consideration the existing arrangements. There are cases in which the construction of new buildings, within the new arrangement of space, unavoidably replaced, in terms of function, earlier buildings. As a result, today the Meteora monasteries demonstrate a variety of continually changing spatial arrangements, with buildings of interwoven and conflicting functions.

The changes in the spatial arrangement of the monasteries reflect the failure of the monastic communities to face the wider changes affecting the operation of their site (the re-establishment of the monastic communities on the site, the formation of the large congregation and its participation in the ritual life, and the development of tourism) in terms of proactive and long-term planning. Every time there is a wider change in the operation of the site, the monastic communities tend to substantially change the earlier arrangement of space. The changes in the spatial arrangement of the monasteries also reflect the failure of the monastic communities to cooperate with each other and come to a unified planning of the use of space for all the monasteries. Thus, though the wider changes affecting the operation of the site are common for all the monasteries (though appearing at each of them in slightly differing periods, which has to do with the specific circumstances in each monastery), the monastic communities do not share their experiences concerning the changing use of space, and tend to repeat the same mistakes.

It seems, however, that the monastic communities do not realise in the first place the importance of a proactive, long-term and unified planning of the use of space. They tend to feel that their financial power, mostly derived from tourism, allows them the 'luxury' to afford any further changes in terms of spatial arrangement.

\subsection{Analysis}

The Meteora monastic communities, as a result of their acceptance of tourism in the context of their adoption of the philanthropic-missionary approach to monasticism, unavoidably become suppressed in their space under the pressure of tourism. This suppression takes the following forms. 


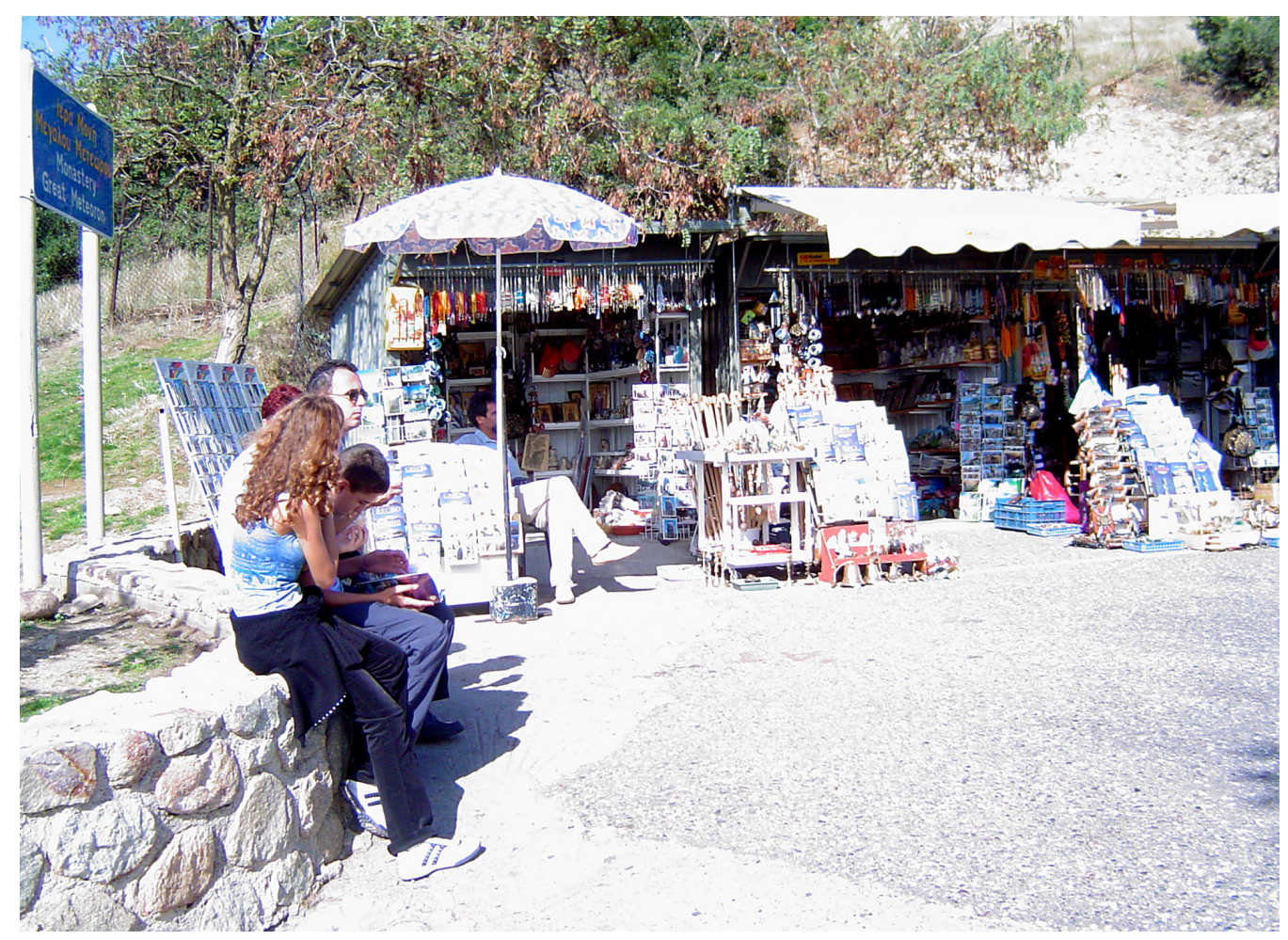

Figure 41: The Great Meteoron monastery: visitors at the entrance of the monastery (source: author's photo). This figure shows that the external space of the monasteries is used exclusively by the visitors and, consequently, the monastic communities become restricted within their monasteries.

1) The monastic communities become increasingly deprived of the use of the external space of the monasteries.

As a result of the presence of visitors, the monks and nuns are deprived of the use of the external space, and are obliged to stay within their individual monasteries (figure 41).

2) The monastic communities become restricted within the internal space of the monasteries.

As a result of the presence of visitors, the once unified internal space of the monasteries is now divided between the monks-nuns and the visitors (figures $\mathbf{4 2 , 4 3 , 4 4}$ and 45 ). It should be stressed that, as a consequence of this division, in most of the monasteries the visitors do not even see the monks and nuns but only the maintenance staff (i.e. private staff hired by the monks to serve the visitors). That is why the majority of the non-Orthodox visitors get the impression that the monasteries are no longer in use (pers. comm. Meteora visitors).

Visitors have access to entire monasteries. The katholicon, though retaining its strongest symbolic and liturgical significance, ceases to serve as the constant point of reference for the everyday life of the monks and nuns. The refectory has, in most of the cases, been transformed into a museum for the exhibition of monastic 'treasures' for the visitors (as in the St Stephen, the Great Meteoron and the Varlaam monasteries), and thus its sacred and symbolic character in connection to the katholicon is lost. The yard is occupied by visitors, which makes the conduct of the communal activities [diakonimata] impossible. The secondary monastic buildings on the periphery within the monastery (such as kitchen, hospital, home for the elderly, guesthouse and various types of storerooms) are also transformed into museums for visitors (as in the Great Meteoron 


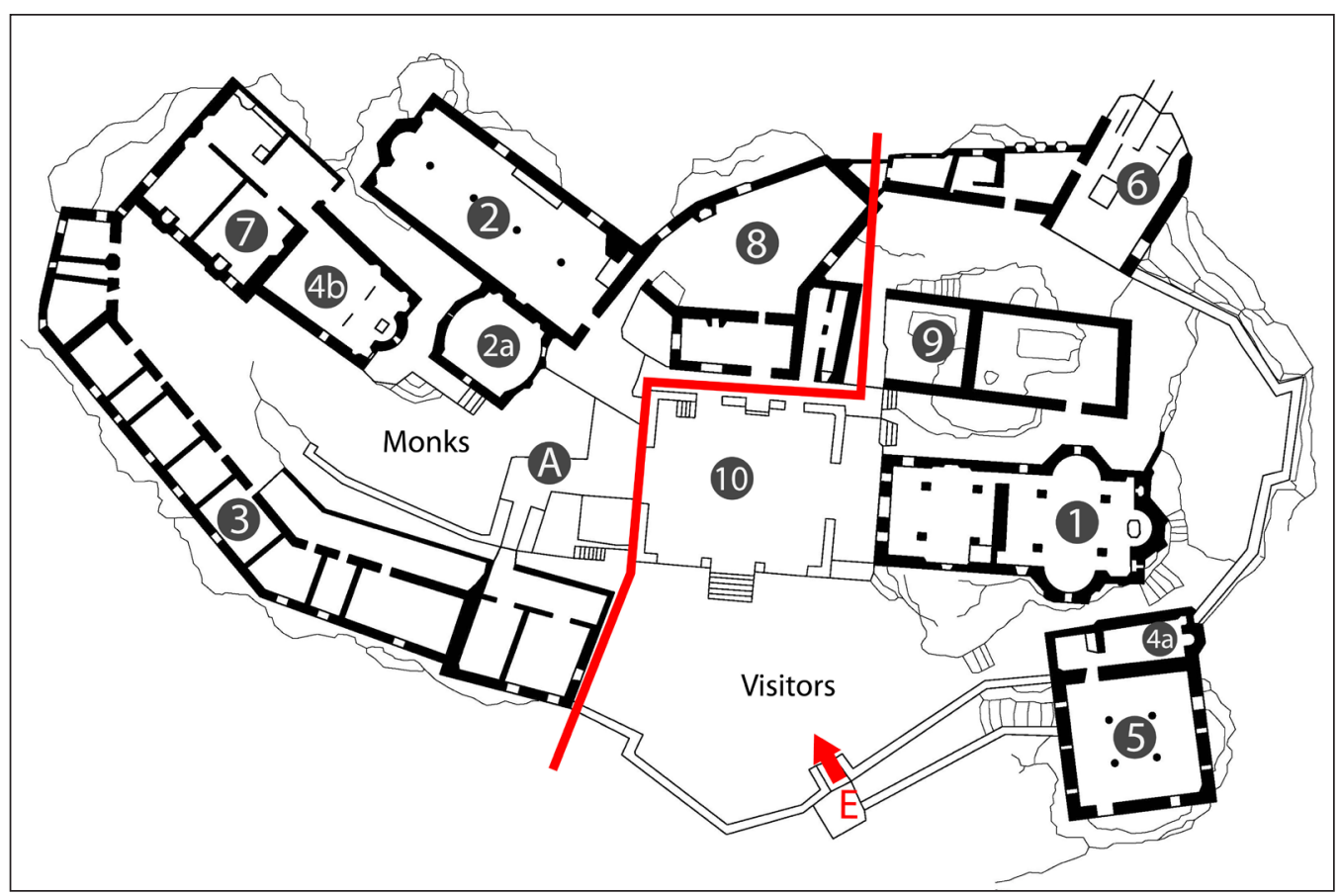

Figure 42: The Varlaam monastery: current use of space (see Papaioannou 1977, 30, with author's additions). This figure shows the division of the internal space of the monastery between the visitors and the monks. The marked line is the dividing line between the space used by the visitors (to the right of the line) and the space used by the monks (to the left of the line). Point $\mathrm{A}$ marks the dividing point between the two spaces (the door kept closed, depicted in figure 43). 1: Katholicon. 2: Refectory. 3: Cells. 4a: Church. 4b: Chapel. 5: Home for the aged, transformed into a museum of monastic 'treasures'. 6: Vrizoni tower (i.e. the original way of access to the monastery). 7, 8, 9: Secondary buildings (the building 7 is transformed into a kitchen and a small refectory for the monks). 10: Yard. E: The current entrance.

and the Varlaam monasteries). The reception hall retains its character but serves the needs of the congregation and important visitors to the monasteries.

Consequently, the monastic communities feel the need to create a new monastic space with all the necessary buildings (figure 45) such as: a new subsidiary church that might replace, in terms of function, the katholicon during the opening hours of the monastery, a new refectory, a new kitchen and new cells, new secondary monastic buildings, a new entrance (for example, through a cable car, as in the Great Meteoron, the Varlaam and the Holy Trinity monasteries: figures $\mathbf{4 6}$ and 47), and space for the conduct of communal monastic activities [diakonimata]. Therefore, what the monastic communities require and create is not simply some additional, supplementary space for their existing monasteries but in some cases a completely new monastic space within their existing monasteries.

The traditional usage of space is no longer possible. The pressure of tourism has removed the essential nature of monastic life in terms of physical layout, and thus the spatial concepts in which Orthodox monasteries are best understood (see above) no longer apply. The arrangement of space is defined by the needs of the visitors rather than the needs of the monastic community, and thus the monasteries have become extroverted rather than introverted units, something that is not in accordance with the Orthodox monastic Tradition (see above). The katholicon, i.e. the 


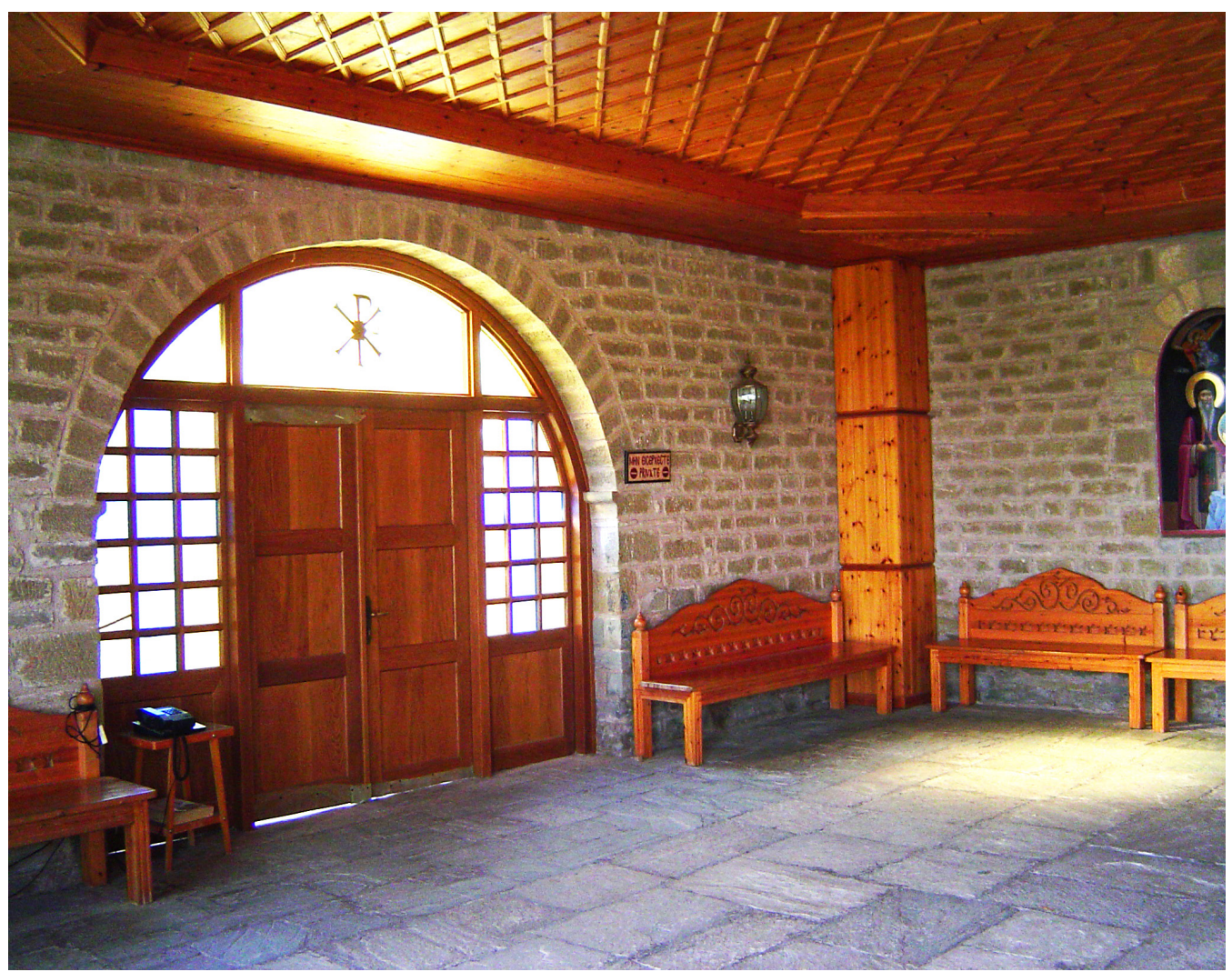

Figure 43: The Varlaam monastery: internal view A (source: author's photo). This door is the dividing point between the space for the visitors and the space for the monks (see figure 42).

quintessential building of a monastery (linked to the worship of God), has become the primary visitor attraction in a monastery. This means that the linkage between the katholicon (religious content) and the yard (human content) is lost, and the approach of Papaiaoannou (see above) no longer applies to the Meteora monasteries today. The yard is exclusively used by the visitors and not the monastic community, which means that the linkage between the life of the monastic community and the visitors is lost. This complete separation between the life of the monastic community and the visitors, and the subsequent division of the two spaces, is an aspect of the Catholic (and not the Orthodox) monastic tradition (see above). Finally, the new space created by the monastic communities is an immediate and rather superficial response to the increasing pressure of tourism rather than a conscious attempt to follow the established rules of the Orthodox monastic Tradition. This was illustrated by the decision of the St Stephen monastic community to give into the desire of the visitors to have access to the katholicon of St Stephen in addition to the katholicon of St Charalambos (see above).

3) The monastic communities become restricted within the internal space, which expands towards the external space of the monasteries.

This expansion of the internal space is achieved through the addition of new buildings which are essentially whole new monasteries, as in the case of the Roussanou new buildings. In this case the division of space is more clear-cut than in the previous one (case 2 above): the visitors have access to the original monastery, while the monks and nuns mainly use the new buildings (see above, figure 32). 


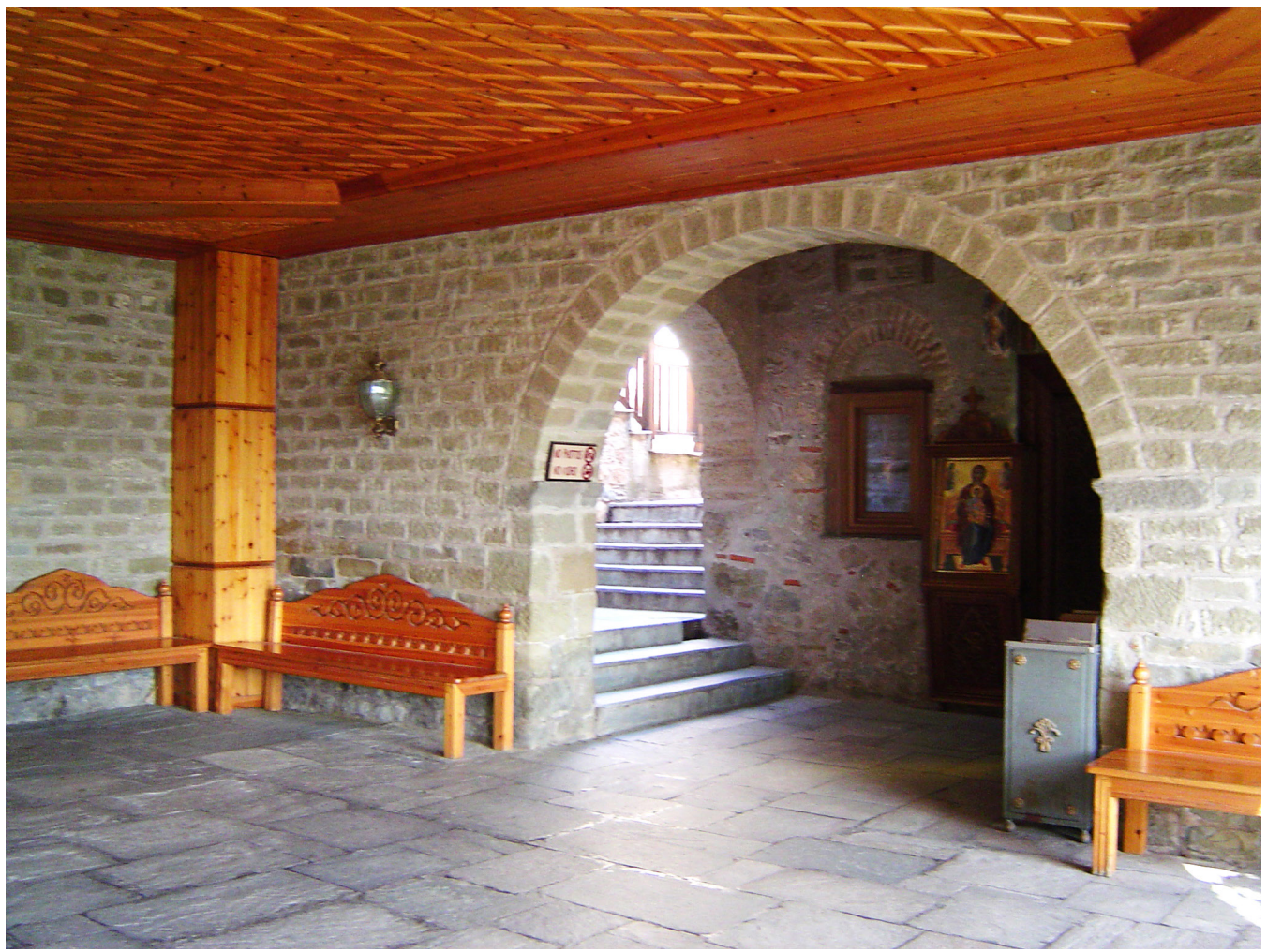

Figure 44: The Varlaam monastery: internal view B (source: author's photo). This is the space (to the right of the monastery: see figure 43) used by the visitors. The entrance to the katholicon is on the right hand side, on the right to the icon. This figure shows that the visitors occupy the largest part of the monastery, including the katholicon.

4) The monastic communities move out of their monasteries to the external space of the monasteries.

The monastic communities form dependencies [metochia] within the site that operate as hermitages, as in the cases of the Great Meteoron, the Holy Trinity, the Varlaam and the St Stephen monasteries (eg. the skiti of St Nikolaos Badovas, which operates as a hermitage of the Holy Trinity Monastery: see above, figure 14). The monks and nuns stay in their hermitages during the opening hours of their monasteries. There are cases, however, where the monks and nuns prefer to stay in their hermitages even outside the opening hours of their monasteries (pers. comm. Varlaam Monastery), which may reveal their increasing tendency to stay away from their monasteries because of the increasing pressure of tourism.

5) The monks and nuns move out of their monasteries to a different site.

From the 1970s until now a large number of monks and nuns, approximately eighty, have abandoned the site for different monastic sites (pers. comm. Tetsios).

Apart from the aforementioned, rather unavoidable, changes in the spatial arrangement, as a result of the monastic communities' restriction within their monasteries because of tourism, the monastic communities cause deliberate changes to the spatial arrangement as a result of their specific response to tourism. Thus, the differing responses of the Meteora monastic communities to tourism, in accordance with their differing commitment to the philanthropic-missionary approach to monasticism, lead to different spatial arrangements. Specifically, the monastic communities that actively embrace tourism, such as the Great Meteoron and St Stephen, tend to 


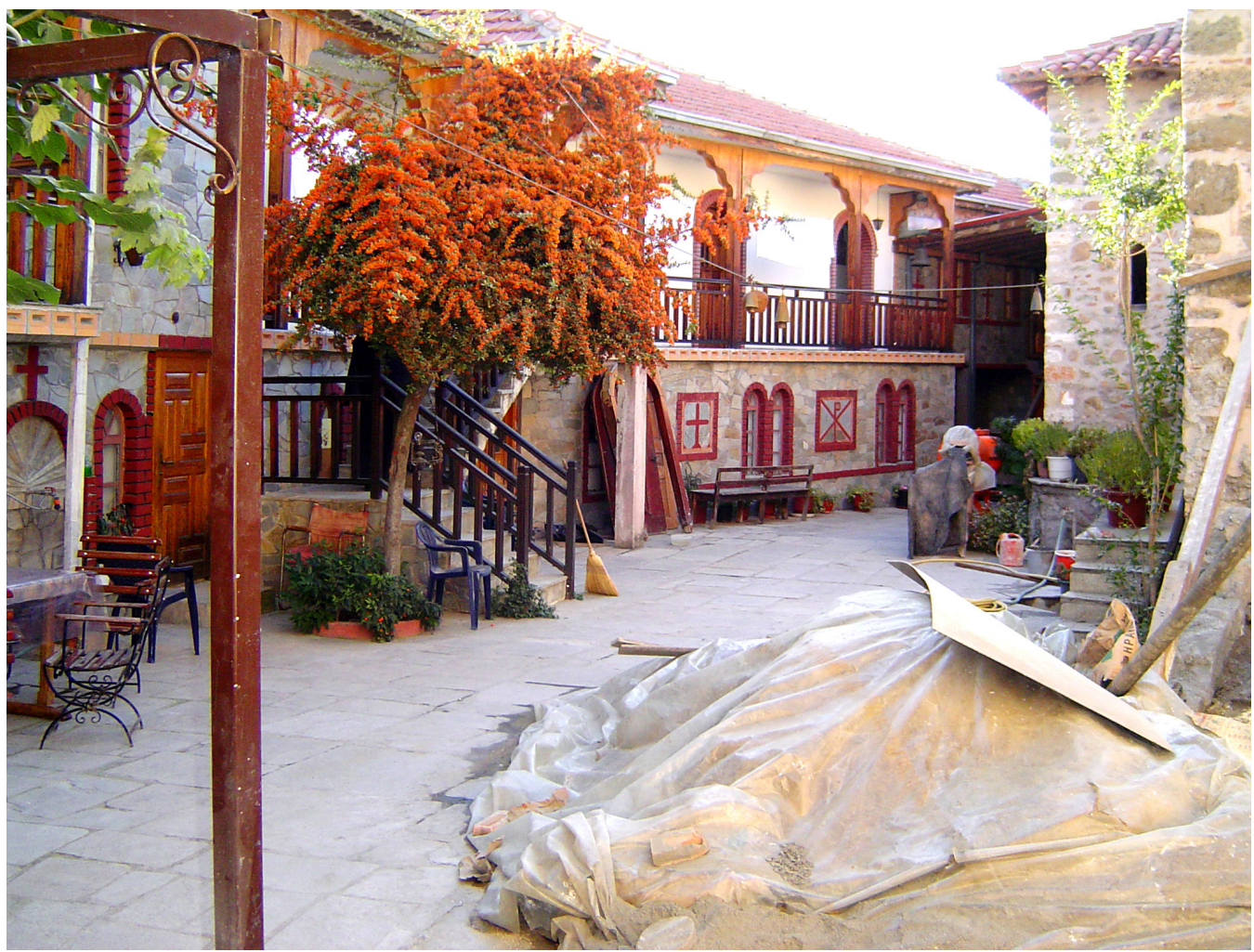

Figure 45: The Varlaam monastery: internal view C (source: author's photo). This is the space (to the left of the door: see figure 43) used by the monastic community. Construction works are in progress. Due to the fact that the visitors occupy the largest part of the monastery, including the katholicon (see figure 44), the monastic communities have to create new space within the monastery (as indicated by the construction works).

deliberately arrange the space mostly according to the needs of the visitors rather than their own needs. These communities show an increasing concern over the following: how to accommodate the largest possible numbers of visitors and how to encourage them to extend their visit to their monasteries for as long as possible; how to meet the needs of the visitors; and what messages to convey and promote to the visitors (Anastasiou 2004). First, these communities place an increased emphasis on the formation of the internal yard and corridors for the visitors to move within the monastery (as in the Great Meteoron, the St Stephen and the Varlaam monasteries). Second, they focus on the formation of museums/exhibition halls for the visitors. There is a great variety of museums/exhibition halls: museums for the exhibition of monastic 'treasures' such as icons, wall paintings and manuscripts (as in the Great Meteoron, the St Stephen and the Varlaam monasteries); storerooms with tools used in agriculture and barrels for the storing of wine, no longer in use (as in the Great Meteoron and the Varlaam monasteries); kitchens with cooking utensils, no longer in use (as in the Great Meteoron monastery); ossuary, no longer in use; the vrizoni towers, no longer in use (as in the Great Meteoron and the Varlaam monasteries); halls with exhibition of photos about the past life and the landscape of the site (as the photos of Kostas Balafas in the Great Meteoron monastery); halls with historical and folklore treasures (in the Great Meteoron monastery). Third, these monastic communities focus on the development of visitor shops. For example, the Great Meteoron, the St Stephen and the Varlaam monasteries have two or three shops each, sometimes selling even tourist souvenirs (as in the Great Meteoron monastery). Fourth, these 


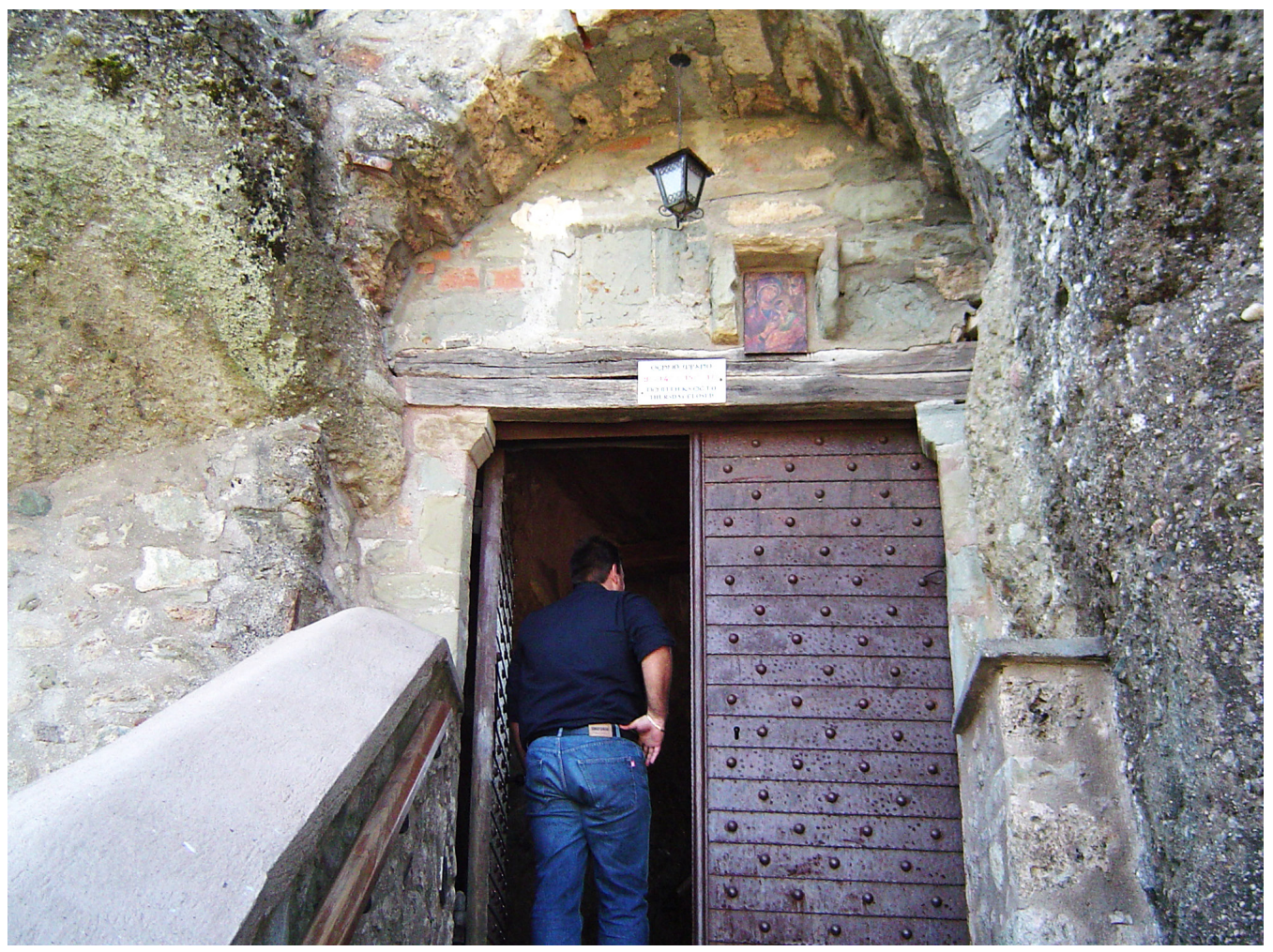

Figure 46: The Varlaam monastery: the entrance (source: author's photo).

communities are concerned about the promotion of the Orthodox faith to the visitors through labels with small extracts from the Holy Scriptures in Greek and English (as in the Great Meteoron monastery). Fifth, these communities tend to show a special concern about the promotion of the national Greek history and identity to the visitors, with an emphasis on the participation of the monastic communities and the Church as a whole in the struggles of the nation. For example, the hall with historical and folklore treasures in the Great Meteoron monastery exhibits, among others, a model of the Parthenon, national flags and posters from recent wars of Greece.

The monastic communities that have a more passive approach to tourism, such as the Holy Trinity and Roussanou, tend to arrange the space mainly according to their own needs without a special care for the visitors. It is worth stressing, for example, that the Holy Trinity monastery, unlike all the other Meteora monasteries, has no shops for the visitors, something that constitutes a deliberate choice of the Abbot (pers. comm. Tetsios).

The use of space is also linked to the everyday tourism operation of the monasteries. The monasteries of those communities with an active approach to tourism (as the Great Meteoron and St Stephen) attract the largest numbers of visitors, while the monasteries of those communities with a passive attitude towards tourism (as the Holy Trinity and Roussanou) attract a much smaller number of visitors.

\section{Conclusion}

This section demonstrated how the main problems in the operation and management of the site, as a result of the monastic communities' acceptance of tourism in the context of their philanthropic approach to monasticism (i.e. separation between monasticism and tourism operation; 

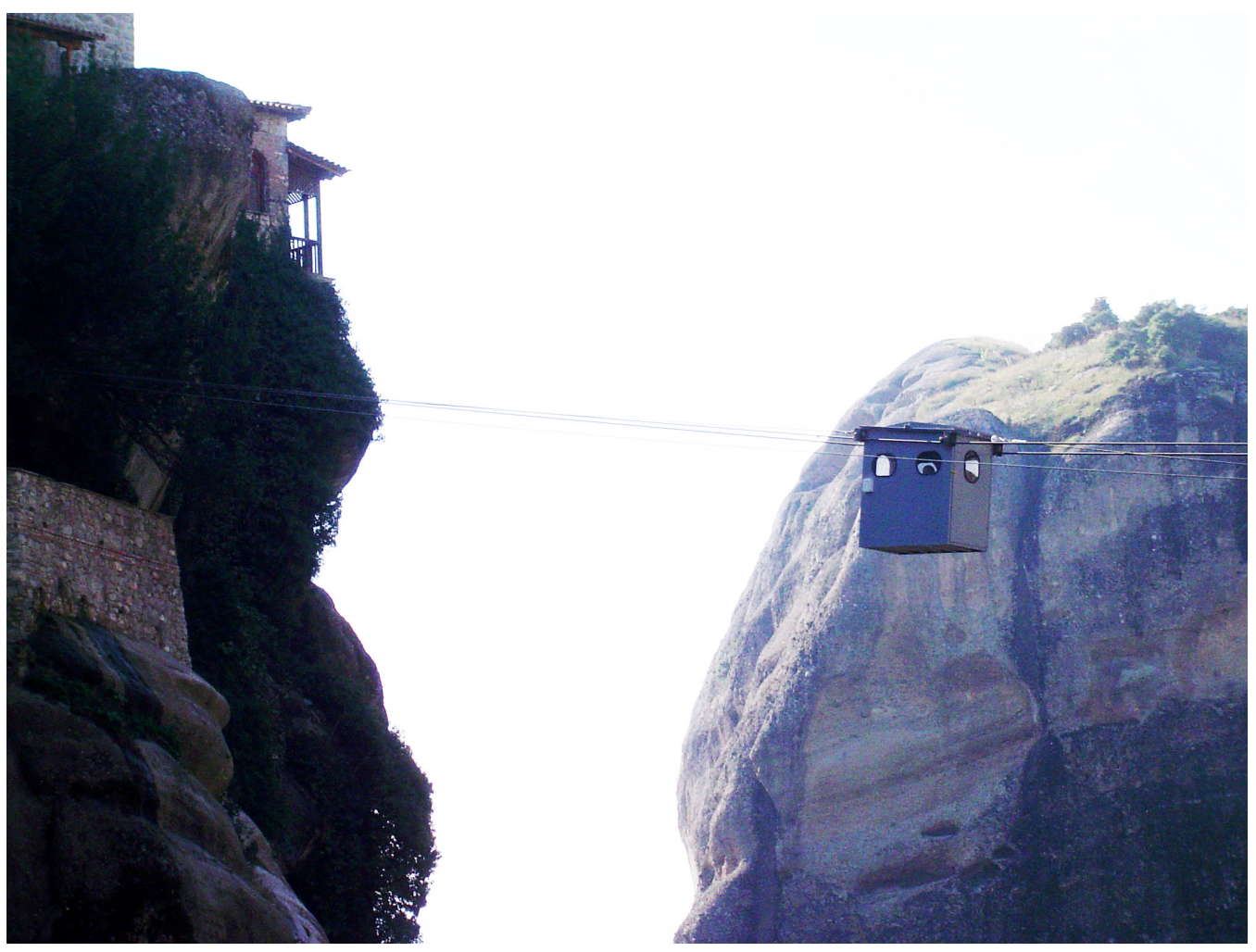

Figure 47: The Varlaam monastery: the cable car (source: author's photo). These figures show different types of access to the monasteries: the monks (as well as the important visitors) use the cable car, while the rest of the visitors use the entrance of the monastery.

increased emphasis on tourism; and adjustment of monastic life to the pressure of tourism: see above), are manifested through changes in the use and arrangement of the monastic space. The monastic communities become increasingly restricted within their space. The space is clearly divided between the monastic communities on the one hand, and the visitors on the other.

The monastic communities find it difficult to conduct their worship of God in the existing space, and thus create new spaces. This is not a matter of seeking some additional, supplementary space that would provide them some help with practical issues in their monastic life, but an existential need of theirs.

The visitors are excluded from the worship of God. They are also significantly hindered from communicating with the members of the monastic communities. The fact that in most of the monasteries they do not even see the monks and nuns (but only private staff hired to cover their practical needs) creates the impression to the majority of the foreign visitors that the monasteries are no longer in use. This demonstrates that the more the monastic communities attempt to open their monasteries towards the visitors and embrace them, in the context of the philanthropic-missionary approach to monasticism (instead of keeping their monasteries closed and introverted, focusing on the worship of God, in accordance with the Orthodox monastic Tradition: see above), the more they actually exclude them from participating in, sharing and even recognising the function of the site as a place of worship of God.

Only the congregation of the monasteries, mostly part of the local community, participates in the worship of God, something that is yet not in accordance with the Orthodox monastic Tradition (see above; see also Moisis 1997, 32). 